IRAN IN MOTION 
This page intentionally left blank 


\title{
IRAN IN MOTION
}

Mobility, Space, and the Trans-Iranian Railway

\author{
Mikiya Koyagi
}

Stanford University Press

Stanford, California 
STANFORD UNIVERSITY PRESS

Stanford, California

(C) 2021 by the Board of Trustees of the Leland Stanford Junior University.

All rights reserved.

No part of this book may be reproduced or transmitted in any form or by any means, electronic or mechanical, including photocopying and recording, or in any information storage or retrieval system without the prior written permission of Stanford University Press.

Printed in the United States of America on acid-free, archival-quality paper

Library of Congress Cataloging-in-Publication Data

Names: Koyagi, Mikiya, author.

Title: Iran in motion : mobility, space, and the Trans-Iranian Railway / Mikiya Koyagi.

Description: Stanford, California : Stanford University Press, 2021. | Includes bibliographical references and index.

Identifiers: LCCN 2020034453 (print) | LCCN 2020034454 (ebook) | ISBN 9781503613133 (cloth) | ISBN 9781503627673 (ebook)

Subjects: LCSH: Railroad travel-Iran-History-2oth century. | Railroads-Social aspects-Iran-History-2oth century. | Iran-History-Mohammad Reza Pahlavi, 1941-1979.

Classification: LCC HE3368 .K68 2021 (print) | LCC HE3368 (ebook) | DDC $385.0955 / 09044-\mathrm{dc} 23$

LC record available at https://lccn.loc.gov/2020034453

LC ebook record available at https://lccn.loc.gov/2020034454

Cover design: Rob Ehle

Cover photo: Railway construction in Khuzestan. E. Park Album.

Courtesy of the COWI Archives

Typeset by Kevin Barrett Kane in 10.2/14.4 Minion Pro 
For my parents 
This page intentionally left blank 